\title{
Hydration curve and physiological quality of maize seeds subjected to water deficit
}

\section{Curva de hidratação e qualidade fisiológica em sementes de milho sob déficit hídrico}

\author{
Camila Segalla Prazeres ${ }^{1}$; Cileide Maria Medeiros Coelho ${ }^{2 *}$
}

\begin{abstract}
The hydration pattern associated with the physiological quality of seeds can be an early indicator for the evaluation of seed quality. The present study aimed to evaluate the hydration pattern of seeds subjected, or not, to water restriction, and to relate these patterns to their physiological quality. The physiological quality of seeds from five maize lines (L1, L2, L3, L4, and L5) and four hybrids (HT1, HT2, HS1, and HS2) was initially determined using seed germination and vigor tests (accelerated ageing and electric conductivity). A completely randomized experimental design was used with four repeats for the physiological analyses and a regression analysis was performed in order to assess the behavior of the seeds over time. The hydration curve was determined by imbibing the seeds in distilled water $0,0 \mathrm{MPa}$ (control) and in a $-0.9 \mathrm{MPa}$ osmotic solution of polyethylene glycol 6000 . Water uptake by the seeds was found to follow a triphasic pattern in the absence of water stress $(0.0 \mathrm{MPa})$, however, when exposed to a $-0.9 \mathrm{MPa}$ osmotic potential, an extended phase II was observed. Diversity was observed between the lines in terms of the hydration pattern of the seeds, which can influence the physiological quality of the hybrid seeds. Regarding the hybrids, a positive relationship was observed between the shortest time to root protrusion and the quality of the seeds, both with or without water restriction, which allows us to conclude that hydration pattern can be used as a parameter for the early evaluation of physiological quality in hybrid maize seeds.
\end{abstract}

Key words: Zea mays L. Hydration pattern. Osmotic potential. Vigor.

\section{Resumo}

O padrão de hidratação associado à qualidade fisiológica das sementes pode ser um indicativo para avaliação da qualidade de forma precoce. Objetivou-se neste trabalho avaliar o padrão de hidratação das sementes, submetidas ou não à restrição hídrica e relacioná-lo com a qualidade fisiológica das sementes. Inicialmente, determinou-se a qualidade fisiológica das sementes de cinco linhagens (L1, L2, L3, L4 e L5) e quatro híbridos de milho (HT1, HT2, HS1 e HS2) através do teste de germinação e testes de vigor (envelhecimento acelerado e condutividade elétrica). Utilizou-se o delineamento experimental inteiramente casualizado, com quatro repetições para as análises fisiológicas e análise de regressão a fim de analisar o comportamento das sementes ao longo tempo. A curva de hidratação foi realizada com embebição das sementes em água destilada $0,0 \mathrm{MPa}$ (controle) e em solução de PEG 6000 à $-0,9$ MPa. Verificou-se que a absorção de água nas sementes apresentou o padrão trifásico na condição sem estresse hídrico $(0,0 \mathrm{Mpa})$, no entanto, quando expostas à condição de potencial $-0,9 \mathrm{MPa}$, apresentou alongamento da fase II. Houve diversidade entre as linhagens com relação ao padrão de hidratação das sementes, sendo que estas podem influenciar na qualidade fisiológica das sementes dos híbridos. Nos

\footnotetext{
${ }^{1}$ Eng $^{\mathrm{a}} \mathrm{Agr}^{\mathrm{a}}$, Discente de Doutorado, Programa de Pós-Graduação em Produção Vegetal, Universidade do Estado de Santa Catarina, UDESC, Lages, SC, Brasil. E-mail: cami.agro@gmail.com

${ }^{2}$ Eng $^{\mathrm{a}}$ Agr ${ }^{\mathrm{a}}$, Prof ${ }^{\mathrm{a}}$ Dr $^{\mathrm{a}}$ em Ciências, Departamento de Agronomia, UDESC, Lages, SC, Brasil. E-mail: cileide.souza@udesc.br

* Author for correspondence
} 
híbridos, tanto com ou sem restrição hídrica, constatou-se uma relação positiva entre o menor tempo para ocorrência da protrusão radicular e a qualidade das sementes, o que permite concluir que o padrão de hidratação pode ser um parâmetro para avaliação precoce da qualidade fisiológica de sementes de milho híbrido.

Palavras-chave: Zea mays L. Padrão de hidratação. Potencial osmótico. Vigor.

\section{Introduction}

Germination is the result of physiological processes that are sequentially initiated by the absorption of water by the seed (SUNMONU et al., 2016). However, the seeds must reach an adequate level of hydration, which activate their metabolic processes (FONSECA; PEREZ, 2003) allowing the growth of the embryo, and subsequently, of the seedling (NONOGAKI et al., 2010). The hydration of maize seeds follows a triphasic pattern, with different physical and metabolic processes occurring in each phase (BEWLEY et al., 2013); however, when a condition of water deficit is imposed during germination, the hydration pattern can be altered.

The hydration pattern can be linked to physiological quality, and can be used as a parameter for precocious seed evaluation (BORTOLOTTO et al., 2008; ALBUQUERQUE et al., 2009; WRASSE et al., 2009; SMIDERLE et al., 2013). According to Villela et al. (2003), in a study focusing on the hydration of caryopses with or without maize seed embryos, the embryos were hydrated at a faster rate than the caryopsis during the first $48 \mathrm{~h}$, and, in addition, the embryos of the seeds with lower physiological potential absorbed a higher amount of water compared to those composed of more vigorous seeds.

The quality of seeds is defined as a set of characteristics that determine their value for planting, such as the interactions between genetic, physical, sanitary, and physiological attributes, for which the latter includes germination and vigor (MARCOS FILHO, 2015). Seed vigor is a property that determines the potential for the rapid and uniform development of seedlings under a wide range of field conditions (RAJJOU et al., 2012).

The physiological quality of seeds depends on their capacity for cellular organization and the mobilization of resources for the formation of more vigorous seedlings (DELGADO et al., 2015), which vary according to genotype (DINIZ et al., 2015). The use of seeds with high vigor is essential for the speed and initial emergence of maize seedlings (SBRUSSI; ZUCARELI, 2014). The results of germination and vigor tests, which are associated with the hydration pattern of the seeds, can be early indicators of better quality genotypes. The precocious characterization of genotypes, making use of previous evaluations of the physiological quality of their seeds, can be a determining factor in the choice of lines used to obtain new maize hybrids that are also tolerant to water deficit conditions (ABREU et al., 2014).

Water deficit, like many other environmental stresses, adversely affects seed production, and one of the most important stages that can be compromised by this type of environmental stress is germination. Seed vigor can be an indication of tolerance to water deficit (TAVARES et al., 2013); as such, it is probable that a lower physiological potential will present deficiencies in the process of repair and protection of the membrane system during the initial absorption stage, which would negatively affect the later stages of the germination process (COSTA et al., 2008).

In this context, the objective of the present study was to evaluate the hydration pattern of seeds subjected, or not, to water restriction, and to relate these patterns to the physiological quality of the seeds.

\section{Materials and Methods}

The experiments were performed in the Seed Laboratory of the Department of Agronomy of the University of Santa Catarina, CAV/UDESC, in the municipality of Lages, SC. The seeds evaluated were produced in the headquarters of an agribusiness 
company in Coxilha, RS, at an average altitude of $720 \mathrm{~m}$, with latitude $28^{\circ} 07^{\prime} 38^{\prime \prime}$ and longitude $52^{\circ} 17^{\prime} 46^{\prime \prime}$. The average annual temperature was $17.5^{\circ} \mathrm{C}$ and the mean annual precipitation was $1,800 \mathrm{~mm}$. The maize seeds utilized included two triple hybrids (HT1 and HT2), two simple hybrids (HS1 and HS2), and five lines (L1, L2, L3, L4, and L5). The composition of the HT1 triple hybrid refers to the following lines: $(\mathrm{L} 2 \times \mathrm{L} 1) \times \mathrm{L} 4$. The composition of the HT2 triple hybrid was formed from the lines: $(\mathrm{L} 2 \times \mathrm{L} 3) \times \mathrm{L} 5$. The $\mathrm{L} 2 \times \mathrm{L} 1$ cross generated a simple hybrid, named HS1, and that generated by the L $2 \times$ L3 cross was named HS2 Samples that were representative of the fields were collected when the cobs were harvested for use in the laboratory experiment.

Immediately after harvest, the seeds originated from each genitor and the first generation (F1) were taken to the laboratory. Each sample, corresponding to the different lines and hybrids, was reduced by successive divisions in order to obtain a working sample (900 g) (BRASIL, 2009). The working sample was divided into four using a seed divider for homogenization.

The pattern of seed hydration as a function of time was determined under two osmotic potentials: 0.0 and $-0.9 \mathrm{MPa}$. The seeds were imbibed in Germitest ${ }^{\circledR}$ type paper rolls soaked 2.5 times their dry weight in distilled water or polyethylene glycol (PEG) 6000. The amount of PEG 6000 used was determined using the methodology proposed by Villela, et al. (1991). The rolls containing the seeds were kept in the germinator in a vertical position at $25^{\circ} \mathrm{C}$.

Sub-samples formed of $5 \mathrm{~g}$ of seeds were collected during germination in order to determine the hydration curve, using the oven method at $105^{\circ} \mathrm{C}$ (BRASIL, 2009). The water absorption intervals established were $0,12,24,36,48,60$, and $72 \mathrm{~h}$ for water, and 0, 24, 48, 72, 96, 120, 144, 168, and $192 \mathrm{~h}$ for PEG 6000. The percentage water gain was calculated according to the initial and final seed weights. The time to the occurrence of germination in $50 \%$ of the seeds (T50) was determined from the moment the seed roots reached $2 \mathrm{~mm}$, as measured using a caliper.

The initial physiological quality of the seeds was evaluated by the percentage germination and the vigor tests (accelerated ageing and electric conductivity), separate from the seed hydration curve.

The germination test was performed using four sub-samples containing 50 seeds each, using Germitest ${ }^{\circledR}$ type paper, soaked in distilled water up to 2.5 times the weight of the substrate. The rolls containing the seeds remained at $25^{\circ} \mathrm{C}$. The evaluations were performed on the seventh day, considering the seedlings as normal, according to BRASIL (2009).

The accelerated ageing test involved four subsamples of 50 seeds, uniformly distributed on a steel frame in acrylic boxes measuring $11 \times 11 \times 3.5 \mathrm{~cm}$, with $40 \mathrm{~mL}$ of distilled water (MARCOS FILHO, 1999a). The boxes containing the seeds were kept at $45^{\circ} \mathrm{C}$ for $72 \mathrm{~h}$ (BITTENCOURT; VIEIRA, 2006). After this period, the seeds were maintained at $25^{\circ} \mathrm{C}$ for 4 days, at which point the number of normal seedlings was determined.

The electric conductivity test was performed on four sub-samples of 50 seeds, with each repeat sample being previously weighed and placed in a container with $75 \mathrm{~mL}$ of distilled water for soaking, and maintained in a germinator at $25^{\circ} \mathrm{C}$. A digital benchtop conductivity meter (model Q795A2 Quimis) was used to measure conductivity in the $24 \mathrm{~h}$ period after the test was set up. The result obtained with the conductivity meter was divided by the weight of the repeat, so that the final result was expressed in $\mu \mathrm{S} \mathrm{cm}^{-1} \mathrm{~g}^{-1}$ (MARCOS FILHO, 1999b).

A completely randomized experimental design was used for the physiological analyses, with four repeats. The Scott-Knott test was used at 5\% probability to compare the averages, and a regression 
analysis was performed to assess the behavior of the seeds over time. It was not necessary to transform the data. The analyses were performed using the Software SAS System ${ }^{\circledR} 9.0$ (SAS, 2009).

\section{Results and Discussion}

First, the seeds were evaluated for initial humidity content, which was established at around $11 \%$ for the different lines and hybrids used. After the seeds were hydrated in water, they quickly gained weight due to water absorption, characterized as Phase I, which terminated after $12 \mathrm{~h}$ of hydration (Figure 1). Root protrusion (T50) occurred at the end of Phase II, corresponding to 36 or $48 \mathrm{~h}$ of hydration, depending on the genotype. Phase III was again marked by an increase in water absorption by the seeds. The L4 line and the HT1 triple hybrid showed root protrusion at $36 \mathrm{~h}$, whereas root protrusion in the remaining genotypes was observed after $48 \mathrm{~h}$ of seed hydration. This process may influence the speed of future seedling formation.

Figure 1. Hydration patterns of seeds from different maize lines and hybrids, evaluated in water.

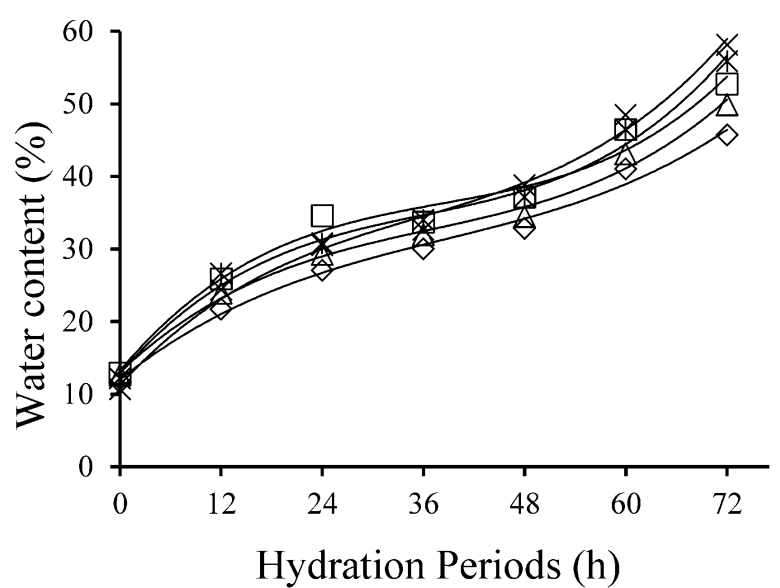

$\diamond$ L1 $y=0,0001 x^{3}-0,0167 x^{2}+0,9308 x+12,040 R^{2}=0,99$

口L2 $\mathrm{y}=0,0003 \mathrm{x}^{3}-0,0307 \mathrm{x}^{2}+1,3865 \mathrm{x}+13,245 \mathrm{R}^{2}=0,98$

$\Delta \mathrm{L} 3 \mathrm{y}=0,0002 \mathrm{x}^{3}-0,0228 \mathrm{x}^{2}+1,0918 \mathrm{x}+13,054 \mathrm{R}^{2}=0,99$

$X \mathrm{~L} 4 \quad \mathrm{y}=0,0002 \mathrm{x}^{3}-0,0259 \mathrm{x}^{2}+1,2616 \mathrm{x}+11,299 \mathrm{R}^{2}=0,99$

*L5 $y=0,0003 x^{3}-0,0304 x^{2}+1,3351 x+12,881 R^{2}=0,99$

Water deficit simulated by the use of PEG 6000 induced different seed behavior, when compared to the hydration pattern observed in water (Figure 2), leading to a prolonged Phase II that resulted in a delay in root protrusion (T50), and occurred 72 to $168 \mathrm{~h}$ after the start of hydration. Root protrusion was observed at 72 and $96 \mathrm{~h}$ in the HT1 hybrid and the L4 line, respectively, whereas the L5 line and the HS2 simple hybrid showed root protrusion only after $168 \mathrm{~h}$ of seed hydration.

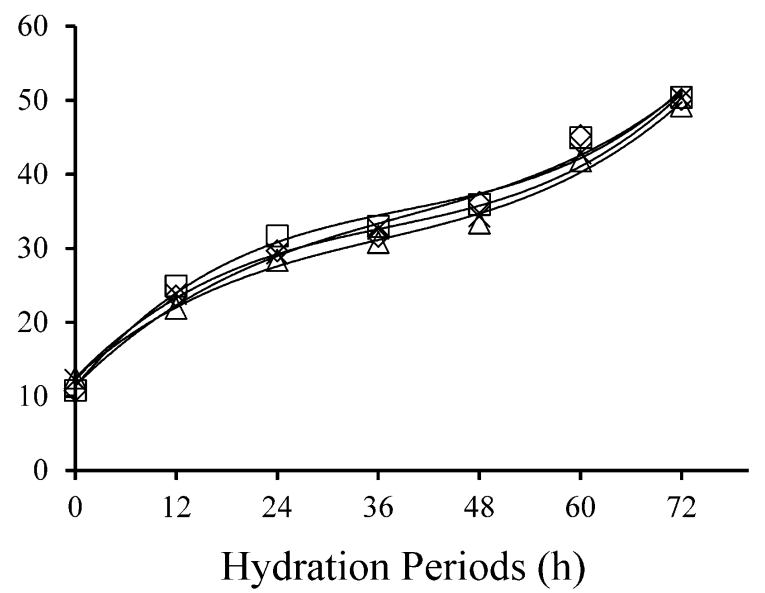

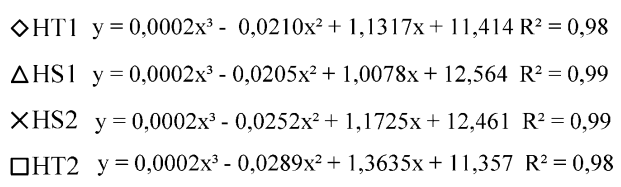

Analysis of hydration pattern behavior can help identify the physiological process occurring in the seed, thus providing a tool that can be used to determine the physiological quality of the different genotypes (EHRHARDT-BROCARDO; COELHO, 2016). By studying the hydration pattern of seeds in water and PEG6000, the results obtained could be related to the initial physiological quality of the seeds. 
Statistically significant differences were observed between the lines and the hybrids in the germination and vigor tests (accelerated ageing and electric conductivity), as shown in Table 1 . The lines differed significantly in terms of the percentage of germination (Table 1), which was not explained by the increased speed of root protrusion. An increased level of germination (88\%) and fast root protrusion in water (36 h), was observed in the L4 line, but the remaining lines (L1, L2, and L3) also showed a high percentage of germination $(94,94$, and $91 \%$, respectively), which was associated with a slower root protrusion time, at $48 \mathrm{~h}$. Root protrusion at $48 \mathrm{~h}$ of hydration was also observed in the L5 line that was used to form the HS2 triple hybrid, which showed a low physiological potential regarding the percentage of germination (75\%).

During the evaluation of hybrids, a heterosis effect was observed in terms of physiological characteristics, which allowed the association to be made between the lowest root protrusion time and the highest physiological quality, due to the capacity of the combined lines.

Comparing the hybrids in terms of the percentage germination, the HT1 triple hybrid showed a high percentage of germination (96\%), which was higher than that of the HT2 triple hybrid (84\%). The elevated physiological potential was shown in the HT1 triple hybrid by the occurrence of root protrusion at $36 \mathrm{~h}$ of hydration, unlike the HT2 triple hybrid, which presented a slower root protrusion at $48 \mathrm{~h}$ of hydration. Despite its high physiological quality, the HS1 simple hybrid showed root protrusion at $48 \mathrm{~h}$, which may have occurred as a result of the particular combination of lines that formed this hybrid, as the L1 and L2 lines also presented a longer hydration time (48 h).

The vigor results obtained from the accelerated ageing test revealed significant differences between the lines and the hybrids. The L1 and L2 lines stood out, with 71 and $84 \%$, respectively. Median results were obtained for the L3, L4, and L5 lines for this test, with 61,54 , and $63 \%$, respectively. The HT1 triple hybrid showed a vigor result of $89 \%$, compared to the HT2 triple hybrid, which presented a lower vigor, of only $22 \%$, since in addition to the low physiological quality of its seeds, it also exhibited a slow water absorption speed.

The results of the electric conductivity test revealed differences between the lines (Table 1). The L1 line, used in the cross that formed the HT1 triple hybrid, was highlighted among the remaining lines at $9.30 \mu \mathrm{S} \mathrm{cm}^{-1} \mathrm{~g}^{-1}$, associated with less solute leaching in the seeds, demonstrating their increased vigor. Conversely, the L5 line, used in the cross that formed the HT2 triple hybrid, showed the lowest vigor in the electric conductivity test, with 19.84 $\mu \mathrm{S} \mathrm{cm} \mathrm{cm}^{-1} \mathrm{~g}^{-1}$, and a longer seed hydration time. The HT1 triple hybrid and the HS1 simple hybrid stood out in this vigor test, with lower solute leaching at 10.81 and $11.54 \mu \mathrm{S} \mathrm{cm}^{-1} \mathrm{~g}^{-1}$, respectively; however, the lowest result was obtained with the HT2 triple hybrid, at $19.56 \mu \mathrm{S} \mathrm{cm}^{-1} \mathrm{~g}^{-1}$. Once again, these results confirmed that the HT1 triple hybrid presented the highest vigor in the root protrusion test ( $36 \mathrm{~h}$ ) and that the seeds of the HT2 hybrid showed elevated electric conductivity and slow root protrusion.

In studies on rice cultivation, Wrasse et al. (2009) observed that it was possible to use the hydration curve (in water) to classify seed lots based on their physiological quality, concluding that this was a promising method to evaluate the physiological potential of rice seeds. The duration of each of hydration phase depends on the inherent properties of the seeds, such as the hydration content of the substrate (BEWLEY et al., 2013). The reduced water potential caused by the use of PEG 6000 is harmful to seed germination (MOTERLE et al., 2008) and influences the behavior of the hydration curve, as observed in the present study. 
Table 1. Germination and vigor percentages, determined by accelerated ageing and electric conductivity tests, in seeds of maize lines and hybrids.

\begin{tabular}{cccc}
\hline \multirow{2}{*}{ Genotypes } & Germination & Accelerated ageing & Electric conductivity \\
\cline { 2 - 4 } & $(\%)$ & $(\%)$ & $\left(\mu \mathrm{S} \mathrm{cm}^{-1} \mathrm{~g}^{-1}\right)$ \\
\hline L1 & Lines & $9.309 \mathrm{a}$ \\
L2 & $94 \mathrm{a}$ & $71 \mathrm{a}$ & $14.686 \mathrm{c}$ \\
L3 & $94 \mathrm{a}$ & $84 \mathrm{a}$ & $12.373 \mathrm{~b}$ \\
L4 & $91 \mathrm{a}$ & $61 \mathrm{~b}$ & $27.423 \mathrm{e}$ \\
L5 & $88 \mathrm{a}$ & $54 \mathrm{~b}$ & $19.842 \mathrm{~d}$ \\
Mean (\%) & $75 \mathrm{~b}$ & $63 \mathrm{~b}$ & 16,72 \\
CV(\%) & 88,20 & 66,40 & 8,74 \\
\hline HT1 & 5,84 & 17,06 & $10.812 \mathrm{a}$ \\
HS1 & & & $11.542 \mathrm{a}$ \\
HS2 & Hybrids & $89 \mathrm{a}$ & $15.295 \mathrm{~b}$ \\
HT2 & $96 \mathrm{a}$ & $93 \mathrm{a}$ & $19.563 \mathrm{c}$ \\
Mean (\%) & $97 \mathrm{a}$ & $63 \mathrm{~b}$ & 14,3034 \\
CV(\%) & $87 \mathrm{~b}$ & $22 \mathrm{c}$ & 9,42 \\
\hline
\end{tabular}

In the column, the averages followed by identical letters do not differ between each other by the Scott-Knott test ( $p>0.05)$.

In the presence of PEG 6000, the L4 line showed fast root protrusion (72 h), which was also observed when the seeds were imbibed in water $(36 \mathrm{~h})$. The HT1 triple hybrid, which showed high physiological quality and rapid water absorption (36 h), also demonstrated increased speed in the absorption curve performed with PEG 6000 (72 h) (Figure 2).

Delayed root protrusion was observed in the L5 line and in its respective hybrid, HT2, and was only reached after $168 \mathrm{~h}$ of hydration in the presence of PEG 6000 (Figure 2), demonstrating that, in addition to being classified as having lower physiological quality, they also exhibited slow root protrusion during the hydration curve of seeds under conditions of negative osmotic potential.
The composition of lines used to obtain the hybrids must be considered in terms of heterosis. A positive relationship was observed between the hydration pattern and the physiological potential of maize seeds. Even though lines with slower root protrusion $(\mathrm{L} 2 \times \mathrm{L} 1)$ were used to generate the HT2 triple hybrid, the L4 line stood out and may have influenced the fast root protrusion ultimately observed in this hybrid. In addition to being formed from the L2 $\times$ L3 lines that showed root protrusion at $48 \mathrm{~h}$, the HT2 triple hybrid was also composed of the L5 line, which not only presented low physiological quality, but also had a negative effect on the hybrid that resulted in slow root protrusion. 
Figure 2. Hydration pattern of seeds from maize lines and hybrids, evaluated using polyethylene glycol 6000 at an osmotic potential of $-0.9 \mathrm{MPa}$.
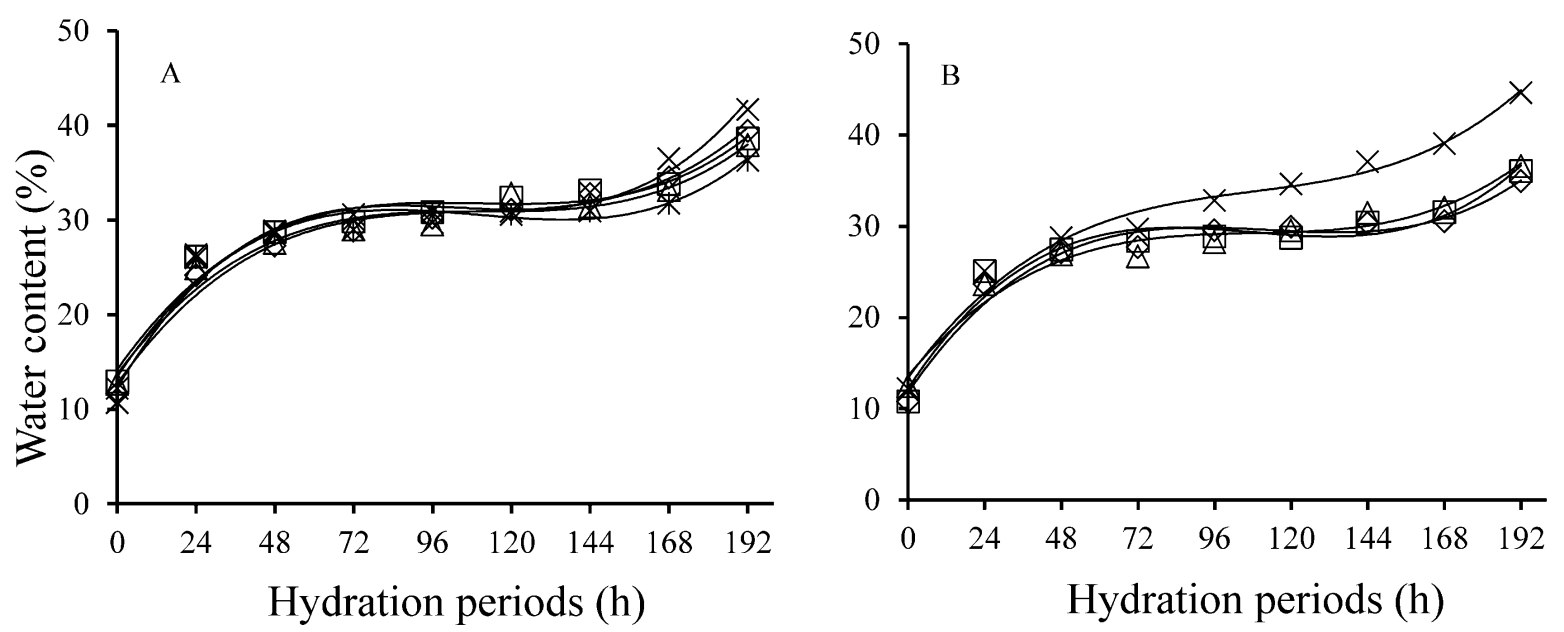

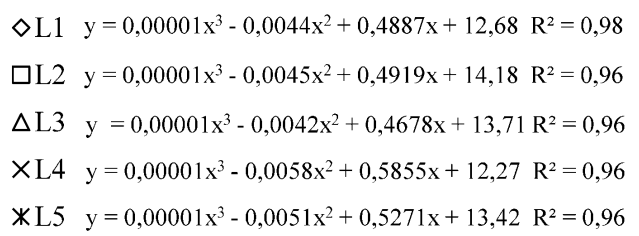

\section{Conclusion}

Diversity in the hydration pattern of the seeds was observed between the lines, and this can influence the physiological quality of the hybrid seeds. Regarding the hybrids, both with or without water restriction, there was a positive relationship between the shortest time to the occurrence of root protrusion and the quality of the seeds, enabling the conclusion to be made that the hydration pattern can be a parameter for the early evaluation of the physiological quality of hybrid maize seeds.

\section{Acknowledgments}

To Semilha Possa \& Cia for the donation of seeds; PROMOP (Programa de Bolsas de Monitoria de Pós-Graduação) for the financial support granted; FAPESC - CP 04/2014 2015 TR 649 (Fundação de Amparo a Pesquisa e Inovação do Estado de Santa Catarina) and $\mathrm{CNPq}$ (Conselho Nacional de Desenvolvimento Científico e Tecnológico) by productivity grant for second author.

\section{References}

ABREU, V. M. de; VILELA, É. V. de R.; VON PINHO, R. G.; NAVES, G. M. de F.; NETA, I. C. S.; GUimarÃeS, R. M.; CARVAlHO, M. R. De. Physiological performance and expression of isozymes in maize seeds subjected to water stress. Journal of Seed Science, Londrina, v. 36, n. 1, p. 40-47, 2014.

ALBUQUERQUE, K. S.; GUIMARÃES, R. M.; ALMEIDA, I. F. de; CLEMENTE, A. D. C. S. Alterações fisiológicas e bioquímicas durante a embebição de sementes de sucupira-preta (Bowdichia virgilioides Kunth.). Revista Brasileira de Sementes, Londrina, v. 31, n. 1, p. 12-19, 2009.

BEWLEY, J. D.; BRADFORD, K. J.; HILHORST, H. W. M.; NONOGAKI, H. Seeds: physiology of development, germination and dormancy. $3^{\text {rd }}$ ed. New York: Springer, 2013. $392 \mathrm{p}$.

BITTENCOURT, S. R. M. de; VIEIRA, R. D. Temperatura e período de exposição de sementes de milho no teste de envelhecimento acelerado. Revista Brasileira de Sementes, Londrina, v. 28, n. 3, p. 161-168, 2006.

BORTOLOTTO, R. P.; MENEZES, N. L. de; GARCIA, D. C.; MATTIONI, N. M. Comportamento de hidratação e qualidade fisiológica das sementes de arroz. Bragantia,Campinas , v. 67, n. 4, p. 991-996, 2008. 
BRASIL. Ministério da Agricultura, Pecuária e Abastecimento. Regras para análise de sementes. Ministério da Agricultura, Pecuária e Abastecimento. Secretaria de Defesa Agropecuária. Brasília: Mapa/ACS, 2009. 399 p.

COSTA, C. J.; VILLELA, F. A.; BERTONCELLO, M. R.; TILlmanN, M. Â. A.; MENEZES, N. L. de. Préhidratação de sementes de ervilha e sua interferência na avaliação do potencial fisiológico. Revista Brasileira de Sementes, Londrina, v. 30, n. 1, p. 198-207, 2008.

DELGADO, C. M. L.; COELHO, C. M. M.; BUBA, G. P. Mobilization of reserves and vigor of soybean seeds under desiccation with glufosinate ammonium. Journal of Seed Science, Londrina, v. 37, n. 2, p. 154-161, 2015.

DINIZ, R. P.; PINHO, E. V. D. R. Von; SANTOS, H. O. dos; VON PINHO, R. G.; VEIGA, P. D. O. A.; CARVALHO, M. L. M. De. Physiological quality and protein patterns of corn seeds produced under water and salt stresses. African Journal of Agricultural Research, Lagos, v. 10, n. 42, p. 3962-3967, 2015.

EHRHARDT-BROCARDO, N. C. M.; COELHO, C. M. M. Hydration patterns and physiologic quality of common bean seeds. Semina: Ciências Agrárias, Londrina, v. 37, n. 4, p. 1791-1800, 2016.

FONSECA, S. C. L.; PEREZ, S. C. J. G. Ação do polietileno glicol na germinação de sementes de Adenanthera pavonina L. e o uso de poliaminas na atenuação do estresse hídrico sob diferentes temperaturas. Revista Brasileira de Sementes, Londrina, v. 25, n. 1, p. 1-6, 2003.

.Teste de envelhecimento acelerado. In.: KRYZANOWSKI, F. C.; VIEIRA, R. D.; FRANÇA NETO, J. de B. (Ed.). Vigor de sementes: conceitos e testes. Londrina: Abrates, 1999a. p. 3.1-3.24.

Teste de condutividade elétrica. In.: KRYZANOWSKI, F. C.; VIEIRA, R. D.; FRANÇA NETO, J. B. (Ed.). Vigor de sementes: conceitos e testes. Londrina: ABRATES, 1999b. p. 4.0-4.26.

Fisiologia de sementes de plantas cultivadas. Local: Associação Brasileira de Tecnologia de Sementes - ABRATES, Londrina, 2015. 659 p.

MOTERLE, L. M.; SCAPIM, C. A.; BRACCINI, A. de L.; RODOVAlHO, M. de A.; BARRETO, R. R. Influência do estresse hídrico sobre o desempenho fisiológico de sementes de híbridos simples de milhopipoca. Ciencia e Agrotecnologia, Lavras, v. 32, n. 6, p. 1810-1817, 2008.
NONOGAKI, H.; BASSEL, G. W.; BEWLEY, J. D. Germination- still a mystery. Plant Science, Limerick, v. 179 , n. 6, p. 574-581, 2010.

RAJJOU, L.; DUVAL, M.; GALLARDO, K.; CATUSSE, J.; BALLY, J.; JOB, C.; JOB, D. Seed germination and vigor. Annual Review of Plant Biology, Palo Alto, v. 63, n. 1, p. 507-533, 2012.

STATISTICAL ANALYSIS SYSTEM INSTITUTE SAS. SAS Institute Inc ${ }^{\circledR}$ 2009. Cary, NC, USA, Lic. UDESC: SAS Institute Inc, 2009.

SBRUSSI, C. A. G.; ZUCARELI, C. Germinação de sementes de milho com diferentes níveis de vigor em resposta à diferentes temperaturas. Semina: Ciências Agrárias, Londrina, v. 35, n. 1, p. 215-226, 2014.

SMIDERLE, O. J.; LIMA, J. M. E.; PAULINO, P. P. S. Curva de absorção de água em sementes de Jatropha curcas L. com dois tamanhos. RevistaAgro@mbiente On-line, Boa Vista, v. 7, n. 2, p. 203-208, 2013.

SUNMONU, T. O.; KULKARNI, M. G.; VAN STADEN, J. Smoke-water, karrikinolide and gibberellic acid stimulate growth in bean and maize seedlings by efficient starch mobilization and suppression of oxidative stress. South African Journal of Botany, Pietermaritzburg, v. 102, p. 4-11, 2016.

TAVARES, L. C.; RUFINO, C. D. A.; BRUNES, A. P.; TUNES, L. M. de; BARROS, A. C. S. A.; PESKE, S. T. Desempenho de sementes de soja sob deficiência hídrica: rendimento e qualidade fisiológica da geração F1. Ciência rural, Santa Maria, v. 43, n. 8, p. 1357-1363, 2013.

VILLELA, F. A.; DONI FILHO, L.; SEQUEIRA, E. L. Tabela de potencial osmótico em função da concentração de polietileno glicol 6.000 e da temperatura. Pesquisa Agropecuária Brasileira, Brasília, v. 26, n. 11/12, 1991.

VILLELA, F. A.; MARCOS FILHO, J.; NOVEMBRE, A. D. D. L. C. Estado energético da água na semente de milho no processo de germinação. Revista Brasileira de Sementes, Londrina, v. 25, n. 1, p. 95-100, 2003.

WRASSE, C. F.; MENEZES, N. L. de; MARCHESAN, E.; AMARAL, F.; BORTOLOTTO, R. P. Testes de vigor para sementes de arroze sua relação com o comportamento de hidratação de sementes e a emergência de plântulas. Cientifica, Jaboticabal, v. 37, n. 2, p. 107-114, 2009. 